\title{
Corals of the Aleutian Islands
}

\section{JONATHAN HEIFETZ,* BRUCE L. WING, ROBERT P. STONE, PATRICK W. MALECHA AND DEAN L. COURTNEY}

Auke Bay Laboratory, National Marine Fisheries Service, Alaska Fisheries Science centre, 11305 Glacier Highway, Juneau, AK 99801, USA

\begin{abstract}
A unique feature of the benthic habitat in the Aleutian Islands is the presence of a highly diverse and abundant coral and sponge community. These communities likely provide important habitat for a variety of fish and invertebrate species. Summaries of historical data and recent direct observations with a submersible indicate that the Aleutian Islands may harbour the highest diversity and abundance of coldwater corals in the world. There are 69 documented taxa (species and subspecies) of coral in the Aleutians of which 25 are endemic. Within the Aleutian Islands, there is an increase in diversity of corals west of about longitude $169^{\circ} \mathrm{W}$. This shift in diversity is consistent with the hypothesis of an ecological boundary in the vicinity of Samalga Pass. Given the endemism and high diversity and abundance of corals in the Aleutians, there is evidence that this region is the evolutionary centre of origin for some taxa of coldwater corals.
\end{abstract}

Key words: Aleutian Islands, coral, habitat, species diversity, sponge

\section{INTRODUCTION}

The waters of the Aleutian Islands Archipelago support a diverse benthic community. Trawl survey data, specimens acquired from fisheries bycatch, and in situ observations with a submersible indicate that the Aleutian Islands may harbour the highest abundance and diversity of coldwater corals in the world (e.g. Heifetz, 2002). Corals of the Aleutians include stolon corals (suborder Stolinifer), true soft corals (suborder

*Correspondence. e-mail: jon.heifetz@noaa.gov

Received 4 May 2004

Revised version accepted 21 September 2004
Alcyoniia), sea whips and sea pens (suborder Pennatulacea), gorgonian corals (suborders Scleraxonia, Holaxonia, and Calcaxonia), stony cup corals (order Scleractina), hydrocorals (order Filifera), and black corals (order Antipatharia) (Wing and Barnard, 2004).

The focus of this paper is on coldwater corals (Fig. 1). However, our in situ observations also indicate that together with corals, sponges are a dominant feature of the benthic community at some locations of the Aleutian Islands. Trawl survey data also indicate that sponges are widely distributed and abundant in the Aleutian Islands, but their diversity may not be different from that found elsewhere in Alaskan waters (Malecha et al., 2005).

Our review of the literature, museum records and our verified own collections indicate 86 different taxa (genera, species, or subspecies) of coldwater corals from the Aleutian Islands (Table 1) (see literature cited in Wing and Barnard, 2004). This is probably an overestimate because of the way some of the specimens have been classified. Specimens that were classified only to the genus level (e.g. Clavularia sp.) may be already listed species of the same genus or an undescribed species. More taxonomic work needs to be done on the specimens that have only been classified

Figure 1. Example of coral habitat of the Aleutian Islands. Shown are the gorgonian coral Paragorgia arborea, unidentified hydrocorals, sponges, and hydroids (Alberto Lindner, NOAA Fisheries).

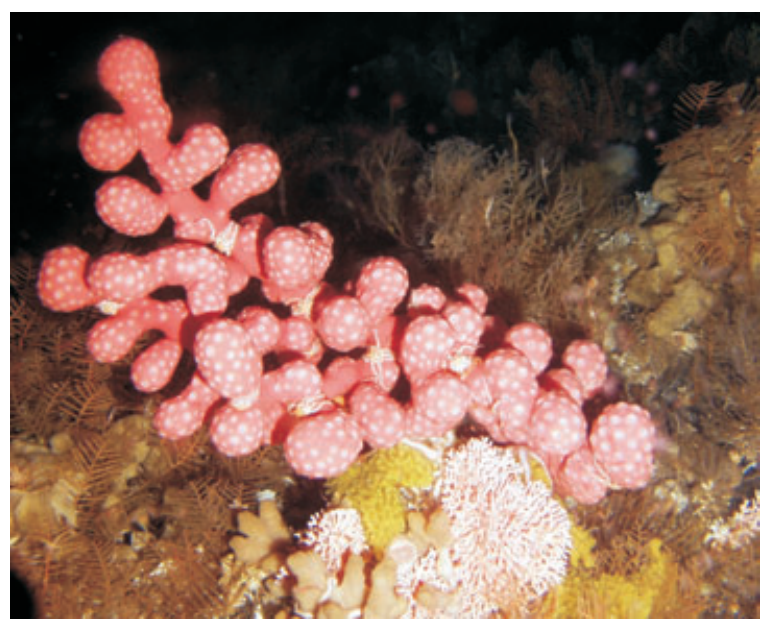


Table 1. Biogeographical distribution of Alaskan coral taxa in the North Pacific Ocean summarized from the literature, verified museum records, and our own verified collections.

\begin{tabular}{|c|c|c|c|c|c|c|c|c|c|c|}
\hline Coral taxa & $\mathrm{J}$ & $\mathrm{SO}$ & WB & $\mathrm{EB}$ & $\mathrm{AL}$ & WG & $\mathrm{EG}$ & SE & $\mathrm{BC}$ & SM \\
\hline \multicolumn{11}{|l|}{ Stolon corals } \\
\hline C. incrustans & & + & + & + & + & & & & & \\
\hline C. incrustans moresbii & & & & & + & + & + & + & + & \\
\hline Clavularia sp. & & & & & + & & & & & \\
\hline \multicolumn{11}{|l|}{ True soft corals } \\
\hline Anthomastus japonicus & + & + & + & + & + & & & & & \\
\hline Anthomastus cf japonicus & & & & & $*$ & & & & & \\
\hline A. ritterii & & & & & + & + & + & + & + & \\
\hline Anthomastus sp. & & & & & + & & & & & \\
\hline Gersemia rubiformis & & & + & + & + & + & + & + & + & \\
\hline Gersemia sp. & & & & & + & & & & & \\
\hline \multicolumn{11}{|l|}{ Gorgonian corals } \\
\hline Alaskagorgia aleutiana & & & & & $*$ & & & & & \\
\hline Amphilaphis sp. (1) & & & & & + & & & & & \\
\hline Amphilaphis sp. (2) & & & & & + & & & & & \\
\hline Amphilaphis sp. (3) & & & & & + & & & & & \\
\hline Arthrogorgia kinoshita & + & + & + & + & + & + & + & + & + & \\
\hline A. otsukai & & + & + & + & + & & & & & \\
\hline A. utinomii & & & & & $*$ & & & & & \\
\hline Calcigorgia beringi & & & & & + & & & + & + & \\
\hline Calcigorgia sp. & & & & & + & & & & & \\
\hline C. spiculifera & & & & & + & + & + & + & + & \\
\hline Corallium sp. & & & & & & & & & & + \\
\hline Euplexaura marki & & & & & + & + & + & + & + & \\
\hline Euplexaura sp. & & & & & + & + & & & & \\
\hline Fanellia compressa & + & + & + & + & + & & & & & \\
\hline F. fraseri & & & & & + & + & & & & \\
\hline Isidella paucispinosa & & & & & + & + & + & + & + & \\
\hline Keratoisis profunda & & & & & + & + & + & + & + & \\
\hline Lepidisis sp. & & & & & & + & + & + & + & \\
\hline Muriceides cf. cylindrical & & & & & $*$ & & & & & \\
\hline M. cylindrical & + & & & & + & & & & & \\
\hline M. nigra & & & & & $*$ & & & & & \\
\hline Muriceides sp. & & & & & + & & & & & \\
\hline Paragorgia arborea & & & & & + & + & + & + & + & \\
\hline P. pacifica & & & & & & & & + & + & \\
\hline Paragorgia sp. & & & & & & & & & & + \\
\hline Paramuricea sp. & & & & & + & & & & & \\
\hline Parastenella sp. & & & & & + & & & & & \\
\hline Plumarella flabellate & + & & & & + & & & & & \\
\hline P. longispina & + & + & + & + & + & + & + & + & + & \\
\hline Plumarella sp. & & & & & + & & & & & \\
\hline P. spicata & & & & & $*$ & & & & & \\
\hline P. spinosa & + & & & & + & & & & & \\
\hline Primnoa resaedaformis pacifica & + & + & + & + & + & & & & & \\
\hline P. reseadaformis & + & + & + & + & + & + & + & + & + & \\
\hline Primnoa reseadformis willeyi & & & & & + & + & + & + & + & \\
\hline Swiftia beringi & & & & & $*$ & & & & & \\
\hline S. pacifica & & & & & $*$ & & & & & \\
\hline S. simplex & & & & & + & & & & + & + \\
\hline Swiftia sp. & & & & & + & & & & & \\
\hline Thouarella hilgendorfi & + & & & & + & & & & & \\
\hline
\end{tabular}


Table 1. Continued.

\begin{tabular}{|c|c|c|c|c|c|c|c|c|c|c|}
\hline Coral taxa & $\mathrm{J}$ & $\mathrm{SO}$ & WB & $\mathrm{EB}$ & AL & WG & $\mathrm{EG}$ & SE & $\mathrm{BC}$ & SM \\
\hline Thouarella sp. & & & & & + & & & & & \\
\hline T. striata & & & & & $*$ & & & & & \\
\hline T. superba & & & & & $*$ & & & & & \\
\hline \multicolumn{11}{|l|}{ Sea whips and sea pens } \\
\hline Anthoptilum grandiflorum & & & + & & & & & & & \\
\hline A. murrayi & + & + & + & + & & & & & & \\
\hline Halipteris californica & & & & & & & & + & + & \\
\hline H. willemoesi & & & & + & + & + & + & + & & \\
\hline Pennatula phosphorea & & & + & + & + & + & + & + & + & \\
\hline P. phosphorea & & & & & & & & + & + & \\
\hline Protoptilum sp. & & & & & & + & + & + & + & \\
\hline Ptilosarcus gurneyi & & & & & + & + & + & + & + & \\
\hline Stylatula elongata & & & & & & & & & + & \\
\hline S. gracilis & & & & & & & & & + & \\
\hline Umbellula lindahli & & & + & + & + & + & + & + & + & \\
\hline Virgularia sp. & & & & & & & + & + & + & \\
\hline \multicolumn{11}{|l|}{ Cup corals } \\
\hline Balanophyllia elegans & & & & & + & + & + & + & + & \\
\hline Caryophyllia alaskensis & & & & & + & + & + & + & & \\
\hline C. arnoldi & & & & & & & & + & + & \\
\hline Caryophyllia sp. & & & & & + & & & & & \\
\hline Crispatotrochus foxi & & & & & + & + & + & + & + & \\
\hline Flabellum sp. & & & & & + & & & & & \\
\hline Fungiacyathus marenzelleri & + & & & & + & & & & + & \\
\hline Javania borealis & + & + & + & + & + & + & & & & \\
\hline J. cailleti & & & + & + & + & + & + & + & + & \\
\hline Leptopenus discus & & & & & + & & & & + & \\
\hline Paracyathus stearnsii & & & & & & & & + & + & \\
\hline \multicolumn{11}{|l|}{ Black corals } \\
\hline Bathypathes alternata & & & & & & & + & + & + & \\
\hline B. patula & & & & & & & + & + & + & \\
\hline Bathypathes sp. & & & & & & & + & + & + & \\
\hline Chrysopathes speciosa & & & & & & & + & + & + & \\
\hline Dendrobathypathes sp. & & & & & & & + & + & + & \\
\hline Lillipathes lilliei & & & & & & & + & + & + & \\
\hline Parantipathes sp. & & & & & & & + & + & + & \\
\hline \multicolumn{11}{|l|}{ Hydrocorals } \\
\hline Crypthelia trophostega & & & & & $*$ & & & & & \\
\hline Cyclohelia lamellate & & & & + & + & & & & & \\
\hline Cyclohelia sp. & & & & & + & & & & & \\
\hline Distichopora borealis & & & & & $*$ & & & & & \\
\hline Distichopora sp. & & & & & + & & & & & \\
\hline Errinopora nanneca & & & & & $*$ & & & & & \\
\hline E. pourtalesii & & & & & + & + & + & + & + & \\
\hline Errinopora sp. & & & & & + & & & & & \\
\hline E. stylifera & & & & & $*$ & & & & & \\
\hline E. zarhyncha & & & & & $*$ & & & & & \\
\hline cf. Stenohelia & & & & & $*$ & & & & & \\
\hline Stylantheca papillosa & & & & & $*$ & & & & & \\
\hline S. porphyra & & & & & & & & + & + & \\
\hline S. petrograpta & & & & & + & & + & + & + & \\
\hline Stylaster alaskana & & & & & $*$ & & & & & \\
\hline S. brochi & & & & & $*$ & & & & & \\
\hline
\end{tabular}


Table 1. Continued.

\begin{tabular}{|c|c|c|c|c|c|c|c|c|c|c|}
\hline Coral taxa & $\mathrm{J}$ & $\mathrm{SO}$ & WB & EB & $\mathrm{AL}$ & WG & EG & SE & $\mathrm{BC}$ & $\mathrm{SM}$ \\
\hline Stylaster campylecus campylecus & & & & + & + & + & + & & & \\
\hline Stylaster campylecus parageus & & & & & & & + & + & + & \\
\hline Stylaster campylecus trachystomus & & & & $*$ & & & & & & \\
\hline Stylaster campylecus tylotus & & & & & $*$ & & & & & \\
\hline S. cancellatus & & & & & $*$ & & & & & \\
\hline S. elassotomus & & & & & $*$ & & & & & \\
\hline S. moseleyanus & & & & & $*$ & & & & & \\
\hline S. polyorchis & & & & & $*$ & & & & & \\
\hline Stylaster sp. & & & & & + & & & & & \\
\hline S. stejnegeri & & & & + & + & & & & & \\
\hline S. venustus & & & & & & & & + & + & \\
\hline S. verrilli & & & & & & & & + & + & \\
\hline
\end{tabular}

Asterisks denote species or subspecies that are endemic to the Aleutians.

J, Japan; SO, Sea of Okhotsk; WB, Western Bering Sea; EB, Eastern Bering Sea; AL, Aleutian Islands; WG, Western Gulf of Alaska; EG, Eastern Gulf of Alaska; SE, Southeastern Alaska; BC, British Columbia and south; SM, Seamounts.

to the genus level. Counting only the taxa that have been classified to the species and subspecies level and those classified to the genus level without multiple species (i.e. Paramuricea sp., Parastenella sp., Amphilaphis sp., and Flabellum sp.), results in 69 taxa of coral in the Aleutian Islands. Although Table 1 does not have black corals occurring in the Aleutians, our just completed sampling during July and August 2004 identified black coral in the Aleutians.

Considering only the taxa that have been identified to at least the species level, results in 25 endemic species and subspecies of coral in the Aleutians (Table 1). Most of the endemic taxa are gorgonians (9) and hydrocorals (15). Newly described, endemic genera and species such as the gorgonian coral Alaskagorgia aleutiana have recently been reported from the Aleutians (Sánchez and Cairns, 2004).

The conservation of coldwater corals and associated communities has stimulated much recent interest because of concern about damage to them caused by fishing gear (e.g. Malakoff, 2003). From a conservation perspective, understanding the ecological and biogeographic mechanisms that play a role in shaping these communities is important. In the Aleutians, corals and sponges form large 'groves,' which are sensitive to human-induced or natural change; some species are believed to live hundreds if not thousands of years (Andrews et al., 2002; Risk et al., 2002). Corals and sponges provide important habitat and refuge for a variety of fish and invertebrates (Freese et al., 1999; Kreiger and Wing, 2002). In the Aleutian Islands, corals and sponges may be 'keystone species' (Tews et al., 2004) that by their presence determine benthic fish and invertebrate diversity and abundance.
Determination of whether corals and sponges are truly keystone species awaits our analysis of in situ dive observations currently underway.

National Marine Fisheries Service trawl survey data can be used to examine geographic trends of coral diversity within the Aleutians. Although there are limitations to this data with regard to consistency of taxonomic identifications and the ability to sample high relief habitat, there is still valuable information for examining general trends (Heifetz, 2002). Many coral names in the database do not represent individual species but instead are various levels of taxonomic groupings. Based on these data, there is an increase in the within-haul diversity of corals in the Aleutian Islands west of about longitude $169^{\circ} \mathrm{W}$ (Fig. 2a,b). For hauls that encountered corals in the eastern section, $96 \%$ of the hauls contain only 1-2 coral taxa, which is typical for most of Alaska's waters. In the western section, the range is $1-14$, and $33 \%$ of the hauls contain more than 2 taxa. This appears to be a distinct boundary, not just an east-west gradient, because immediately west of this boundary there are hauls that have up to 10 coral taxa.

This boundary is consistent with the hypothesis of an ecological boundary in the vicinity of Samalga Pass between Chuginadak and Umnak Islands that has been associated with a partitioning of species distributions of seabirds and zooplankton and a strong front in surface water properties (Coyle, 2005; Ladd et al., 2005). Some taxa of coral occur in both the eastern and western sections, but the overall diversity is much greater west of the boundary (Fig. $2 \mathrm{~b}$ and Table 2). The difference in diversity is mostly due to hydrocorals, gorgonian corals and cup corals. For survey 
(a)

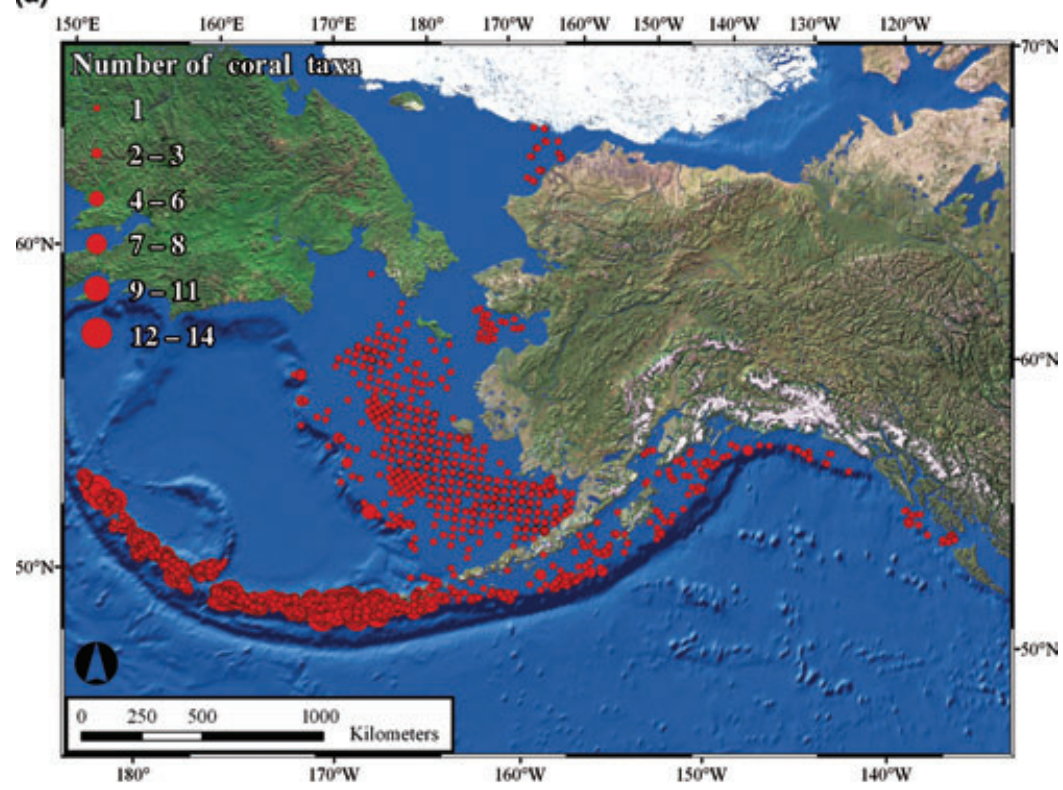

(b)

Figure 2. (a) Diversity of coldwater corals off Alaska based on National Marine Fisheries Service trawl surveys 19902003. Each data point is the number of taxonomic groups in an individual trawl haul. (b) Diversity of coldwater corals in the Aleutian Islands in the vicinity of Samalga Pass based on National Marine Service trawl surveys 1990-2003. Each data point is the number of taxonomic groups in an individual trawl haul.

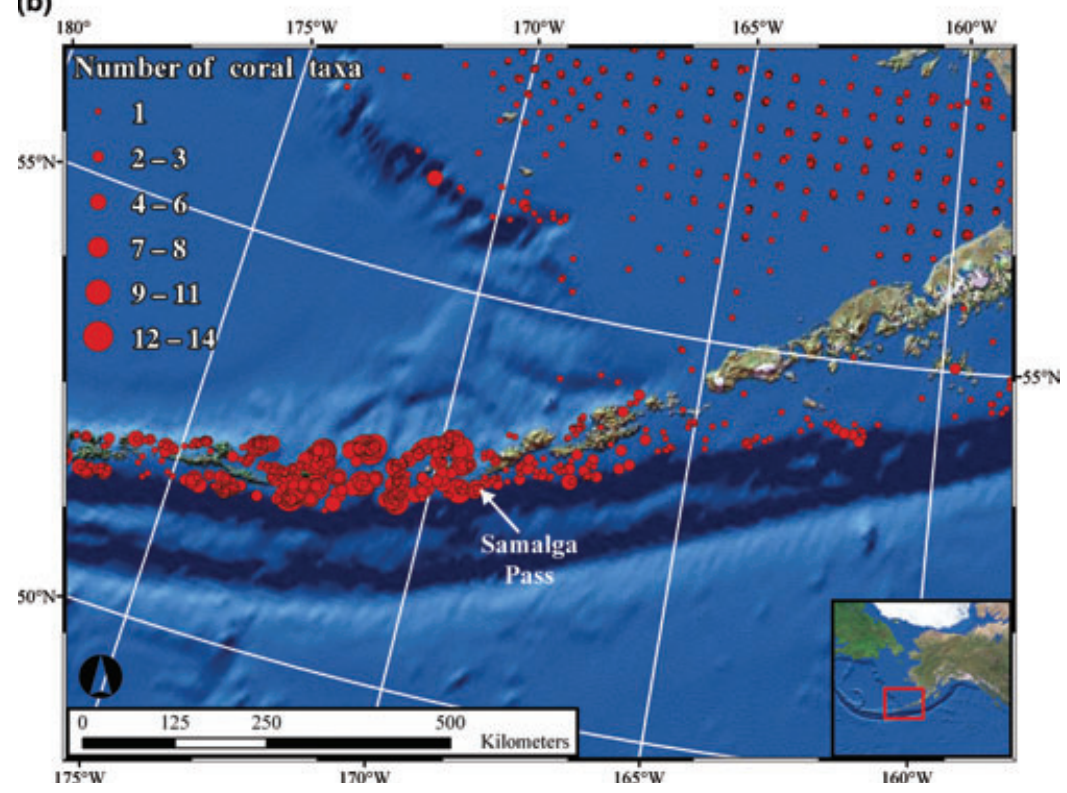

records where specimens were identified to at least the genus level, nine gorgonian corals, four cup corals, and 17 hydrocorals were not collected in the eastern section. In addition, in the eastern section over half of the corals are from two taxonomic groups: $35.0 \%$ sea whips and sea pens and $20.5 \%$ gorgonians in the genus Fanellia. In the western section only $2.7 \%$ of the coral are sea whips and sea pens, and $11.6 \%$ are in the genus Fanellia.

The longitudinal shift in Aleutian coral diversity is likely the result of the interaction of geomorphic, oceanographic and biogeographic processes. Many sessile marine organisms such as corals depend on rocky substrates for recruitment and growth. The Aleutian Island chain is composed of two distinct sections, with a geological boundary that roughly corresponds with the ecological one. The eastern section, which merges into the Alaska Peninsula, comprises islands that rise from the shallow continental shelf. West of the boundary, the Aleutian Islands rest on the narrow crest of the Aleutian Ridge, a mostly submerged mountain range bordered by deep water to the north and south (Vallier et al., 1994). The submarine slopes of this ridge have a much greater (C) 2005 Blackwell Publishing Ltd, Fish. Oceanogr., 14 (Suppl. 1), 131-138. 


\begin{tabular}{|c|c|c|c|c|}
\hline \multirow[b]{2}{*}{ Coral taxa } & \multicolumn{2}{|l|}{ West } & \multicolumn{2}{|l|}{ East } \\
\hline & Frequency & Frequency $(\%)$ & Frequency & Frequency $(\%)$ \\
\hline \multicolumn{5}{|l|}{ True soft coral } \\
\hline Alcyonacea & 55 & 2.07 & 4 & 1.65 \\
\hline Alcyonium sp. & 38 & 1.43 & 2 & 0.82 \\
\hline Alyconaria unidentified & 16 & 0.60 & 6 & 2.47 \\
\hline Anthomastus sp. & 108 & 4.06 & 3 & 1.23 \\
\hline Anthomastus sp. A & 35 & 1.32 & 1 & 0.41 \\
\hline Anthomastus sp. B & 4 & 0.15 & & \\
\hline Gersemia rubiformis & & & 1 & 0.41 \\
\hline Gersemia sp. & 18 & 0.68 & 4 & 1.65 \\
\hline \multicolumn{5}{|l|}{ Gorgonian coral } \\
\hline Amphilaphis sp. & 171 & 6.43 & 15 & 6.17 \\
\hline Amphilaphis sp. 1 & 17 & 0.64 & & \\
\hline Amphilaphis sp. 2 & 27 & 1.01 & & \\
\hline Amphilaphis sp. 3 & 61 & 2.29 & & \\
\hline Arthrogorgia sp. & 35 & 1.32 & & \\
\hline Calcigorgia sp. & 36 & 1.35 & 3 & 1.23 \\
\hline C. spiculifera & 37 & 1.39 & 1 & 0.41 \\
\hline Euplexaura marki & 9 & 0.34 & & \\
\hline Euplexaura sp. & 32 & 1.20 & & \\
\hline Fanellia compressa & 145 & 5.45 & 10 & 4.12 \\
\hline Fanellia fraseri & 43 & 1.62 & & \\
\hline Fanellia sp. & 174 & 6.99 & 42 & 17.28 \\
\hline Gorgonacea & 126 & 4.74 & 10 & 4.12 \\
\hline Keratoisis sp. & 10 & 0.38 & & \\
\hline Muriceides nigra & 1 & 0.04 & & \\
\hline Muriceides sp. & 67 & 2.52 & 6 & 2.47 \\
\hline Paragorgia arborea & 142 & 5.34 & 7 & 2.88 \\
\hline Paragorgia sp. & 22 & 0.83 & & \\
\hline Plumarella sp. & 43 & 1.62 & 4 & 1.65 \\
\hline Plumarella sp. 1 (Bayer) & 84 & 3.16 & 4 & 1.65 \\
\hline Primnoa resaediformes & 2 & 0.08 & & \\
\hline Primnoa sp. & 45 & 1.69 & & \\
\hline Primnoa willeyi & 127 & 4.77 & 5 & 2.06 \\
\hline Swiftia sp. & 9 & 0.34 & 7 & 2.88 \\
\hline Thouarella sp. & 199 & 7.48 & 10 & 4.12 \\
\hline \multicolumn{5}{|l|}{ Sea whips and sea pens } \\
\hline Halipteris californica & 12 & 0.45 & 10 & 4.12 \\
\hline Halipteris sp. & & & 2 & 0.82 \\
\hline Pennatulacea & 23 & 0.86 & 40 & 16.46 \\
\hline Ptilosarcus gurneyi & 4 & 0.15 & 6 & 2.47 \\
\hline Stylatula sp. & 24 & 0.90 & 12 & 4.94 \\
\hline Virgularia sp. & 1 & 0.04 & 2 & 0.82 \\
\hline Virgularidae & 9 & 0.34 & 13 & 5.35 \\
\hline \multicolumn{5}{|l|}{ Cup coral } \\
\hline Caryophyllia alaskensis & 9 & 0.34 & & \\
\hline Caryophyllia sp. & 25 & 0.94 & & \\
\hline Javania borealis & 9 & 0.34 & & \\
\hline J. cailleti & 4 & 0.15 & & \\
\hline Scleractinia unidentified & 100 & 3.76 & 8 & 3.29 \\
\hline \multicolumn{5}{|c|}{ Hydrocorals } \\
\hline Crypthelia sp. & 1 & 0.04 & & \\
\hline C. trophostega & 20 & 0.75 & & \\
\hline
\end{tabular}

Table 2. List of taxonomic names, frequency of occurrence, and percent frequency of occurrence for corals west and east of longitude $169^{\circ} \mathrm{W}$. Data are based on NMFS trawl surveys in waters of the Aleutian Islands 1990-2003. 
Table 2. Continued.

\begin{tabular}{|c|c|c|c|c|}
\hline \multirow[b]{2}{*}{ Coral taxa } & \multicolumn{2}{|l|}{ West } & \multicolumn{2}{|l|}{ East } \\
\hline & Frequency & Frequency $(\%)$ & Frequency & Frequency $(\%)$ \\
\hline Cyclohelia lamellate & 54 & 2.03 & & \\
\hline Cyclohelia sp. & 2 & 0.08 & & \\
\hline Cyclohelia sp. A & 3 & 0.11 & & \\
\hline Distichopora borealis & 12 & 0.45 & 1 & 0.41 \\
\hline Distichopora sp. & 24 & 0.90 & & \\
\hline Errinopora nanneca & 14 & 0.53 & & \\
\hline Errinopora sp. & 31 & 1.16 & & \\
\hline E. zarhyncha & 3 & 0.11 & & \\
\hline Stylaster brochi & 12 & 0.45 & & \\
\hline S. campylecus & 35 & 1.32 & & \\
\hline S. cancellatus & 8 & 0.30 & & \\
\hline S. elassotomus & 5 & 0.19 & & \\
\hline S. moseleyana & 4 & 0.15 & & \\
\hline S. polyorchis & 6 & 0.23 & & \\
\hline Stylaster sp. & 259 & 9.73 & 4 & 1.65 \\
\hline S. stejnegeri & 3 & 0.11 & & \\
\hline S. verrilli & 1 & 0.04 & & \\
\hline Stylasteridae unidentified & 1 & 0.04 & & \\
\hline Stylasterina unidentified & 5 & 0.19 & & \\
\hline
\end{tabular}

depth range and more widespread rocky substrate than the seafloor in the eastern section, which is shallow, close to the continent, and blanketed by sediments deposited primarily during glacial periods (Hampton, 1983). The eastern section has some rocky substrates, but these are more patchily distributed than in the western section.

Oceanographic features, especially strong, nutrientladen currents, are likely favorable for growth of corals. In the Aleutian Islands, strong currents occur more frequently in the western section, particularly through the many deepwater passes between islands in this area. West of Samalga Pass, transport through passes is generally from the nutrient-rich Alaskan Stream (Ladd et al., 2005). Due to more vertical mixing, water properties are more oceanic (i.e. colder, saltier, and more nitrate rich) in the western section than in the eastern section, the latter of which is influenced by the nitrate-depleted and fresher Alaska Coastal Current. The presence of submerged mountain peaks in the western section may cause areas of localized flow acceleration. On these peaks, this accelerated current regime, coupled with the prevalence of exposed rocky substrates, may result in conditions favorable for coral recruitment and growth similar to that on seamounts (Genin et al., 1986).

We do not attempt to demonstrate or hypothesize the linkages between coral diversity and oceanographic/biogeographic patterns. A full understanding of biogeographic patterns would require examination of palaeontology, phylogeny, genetics and empirical data. From the perspective of tropical coral reef ecosystems, Briggs (2004) asserted that the evolutionary origin of successful species, genera and families is from high diversity locations. If this assertion can be generalized for coldwater coral ecosystems, then the endemism and high diversity and abundance of corals in the Aleutians is evidence that the centre of origin for some taxa of coldwater corals is the Aleutian Islands.

Why do the Aleutian Islands have such a high diversity and abundance of coldwater corals? A pilot research program that we initiated in 2002, specifically designed to provide new information on coral and sponge habitat in the Aleutian Islands, may help answer this question. The occupied submersible Delta was used to explore coral habitat in the Aleutians near the Andreanof Islands and on Petrel Bank just north of the Aleutians in the Bering Sea. This was the first and only directed exploration of coral communities at any depth in the Aleutian Islands since the surveys conducted by the RV Albatross nearly a century ago. Preliminary results from this research confirmed the high diversity and wide distribution of corals in the central Aleutians in water less than $365 \mathrm{~m}$ (the depth limit of the Delta). Corals and sponges were found at 30 of the 31 dive sites investigated.

This research expanded in 2003-2004 with multibeam habitat mapping and expanded in situ sampling with the Delta and deeper water (greater than $365 \mathrm{~m}$ ) sampling with the Jason-II remotely operated vehicle. 
Habitat classification of the multibeam maps using the methods of Greene et al. (1999) will enable extrapolation to a broad geographic area of coral densities assessed from in situ sampling. The major objectives of this new research are to: (1) assess the distribution and abundance of corals and sponges in the central Aleutians with respect to major environmental factors and construct a predictive model based on the assessment; (2) determine the importance of corals and sponges as habitat for commercially important fish and invertebrates; (3) evaluate the extent of fishing gear impacts on coral and sponge habitats; and (4) collect corals to describe new species, aid in taxonomic revisions, and determine coral reproductive schedules and larval dynamics. Meeting these objectives will provide information needed for making critical fishery management decisions to protect coral and sponge habitats.

\section{ACKNOWLEDGEMENTS}

We thank Dave Clausen for comments on an early version of this manuscript. Dr Jennifer Reynolds provided information on the geological characteristics of the Aleutian Islands. Kalei Shotwell aided with preparation of figures. Partial funding for the Delta and Jason II submersible observations was provided by the North Pacific Research Board and NOAA's Undersea Research Program.

\section{REFERENCES}

Andrews, A.H., Cordes, E.E., Mahoney, M.M., Munk, J., Coale, K.H., Cailliet, G.M. and Heifetz, J. (2002) Age, growth, and radiometric age validation of a deep-sea, habitat-forming gorgonian (Primnoa resedaeformis) from the Gulf of Alaska. Hydrobiologia 471:101-110.

Briggs, J.C. (2004) Older species: a rejuvenation on coral reefs? J. Biogeogr. 31:525-530.

Coyle, K.O. (2005) Zooplankton distribution, abundance and biomass relative to water masses in eastern and central Aleutian Island passes. Fish. Oceanogr. 14(Suppl. 1):77-92.
Freese, L., Auster, P.J., Heifetz, J. and Wing, B.L. (1999) Effects of trawling on seafloor habitats and associated invertebrate taxa in the Gulf of Alaska. Mar. Ecol. Prog. Ser. 182:119126.

Genin, A., Dayton, P.K, Lonsdale, P.F. and Spiess, F.N. (1986) Corals on seamount peaks provide evidence of current acceleration over deep-sea topography. Nature 322:59-61.

Greene, H.G., Yoklavich, M.M., Starr, R. et al. (1999) A classification scheme for deep-water seafloor habitats. Oceanogr. Acta 22:663-678.

Hampton, M.A. (1983) Geology of the Kodiak Shelf, Alaska: environmental considerations for resource development. Cont. Shelf Res. 1:253-281.

Heifetz, J. (2002) Coral in Alaska: distribution, abundance, and species associations. Hydrobiologia 471:19-28.

Kreiger, K.J. and Wing, B.L. (2002) Megafauna associations of deepwater corals (Primnoa spp.) in the Gulf of Alaska. Hydrobiologia 471:83-90.

Ladd, C.L., Hunt, G.H. Jr, Mordy, C., Salo, S. and Stabeno, P. (2005) Marine environment of the Eastern and Central Aleutian Islands. Fish. Oceanogr. 14(Suppl. 1):22-38.

Malakoff, D. (2003) Cool corals become hot topic. Science 299:195.

Malecha, P.W., Stone, R.P. and Heifetz, J. (2005) Living substrate in Alaska: distribution, abundance, and species associations. In: Benthic Habitats and Effects of Fishing. P. Barnes \& J. Thomas (eds) Bethesda, MD: American Fisheries Society. (in press).

Risk, M.J., Heikoop, J.M. and Beukens, R. (2002) Lifespans and growth patterns of two deep-sea corals: Primnoa resedaeformis and Desmophyllum cristagalli. Hydrobiologia 471:125-131.

Sánchez, J.A. and Cairns, S.D. (2004) An unusual new gorgonian coral (Anthozoa: Octocorallia) from the Aleutian Islands, Alaska. Zool. Med. Leiden 78:265-274.

Tews, J., Brose, U., Grimm, V., Tielborger, K., Wichman, M.C., Schwager, M. and Jeltsch, F. (2004) Animal species diversity driven by habitat heterogeneneity/diversty: the importance of keystone structures. J. Biogeogr. 31:79-92.

Vallier, T.L., Scholl, D.W, Fisher, M.A., Bruns, T.R., Wilson, F.H., von Huene, R. and Stevenson, A.J. (1994) Geologic framework of the Aleutian arc, Alaska. In: The Geology of Alaska. G. Plafker \& H.C. Berg (eds) Boulder, CO: The Geology Society of America, Inc., pp. 367-388.

Wing, B.W. and Barnard, D.R. (2004) A field guide to Alaska corals. U.S. Dep. Commerce, NOAA Technical Memorandum NMFS-AFSC-146, p. 67. 